\title{
Notas sobre o termo e o tema "menor" presentes em performances de raps paulistanos da década de 1990
}

GUILHERME BOTELHO*

\begin{abstract}
RESUMO: Neste artigo, partindo da disputa em torno da tutela sobre a infância e adolescência, traço um resumido percurso histórico a fim de compreender dois pontos: a) como ocorreu a formulação do termo "menor"; b) como os artistas de rap de São Paulo debateram o tema através de suas performances artísticas, às vésperas e logo após a criação e implementação do Estatuto da Criança e do Adolescente (ECA) na década de 1990. Nota-se que o termo "menor" foi um rótulo criado por intelectuais, possui força classificatória e se naturalizou no vocabulário utilizado por parte da sociedade civil, com toda carga pejorativa anexada.
\end{abstract}

PALAVRAS-CHAVE: Rap; Hip Hop; adolescência; maioridade penal.

\section{Notes on the term and the subject "minor" in São Paulo's raps performances of the 1990s}

\begin{abstract}
In this article, starting from the dispute around the guardianship of childhood and adolescence, I trace a historical summary to comprehend two main points: a) how the term "minor" came to be, and; b) how rap artists from São Paulo brought the theme for debate through their artistic performances, in the eve of the creation and introduction of the Child and Adolescent Statute (ECA in Portuguese), and just after it, in the 1990's. It is worth noting that the term "minor" was a label made by intellectuals, but it has a classificatory strength and became natural in the vocabulary of a part of the civil society, attached with a very pejorative charge.
\end{abstract}

KEYWORDS: Rap; Hip Hop; teenager; criminal majority.

\footnotetext{
* Guilherme Botelho é Dj, Bacharel em história pela PUC-SP e Mestrando em filosofia pelo Instituto de Estudos Brasileiro, IEB-USP. E-mail: guibotelho@ymail.com
} 
"Eles tão buscando moleque dentro de casa, daqui a pouco tão buscando dentro da barriga da mãe."1 (Mano Brown)

\section{O termo}

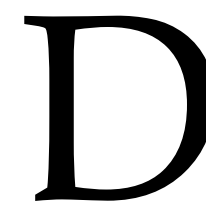
o último quartel do século XIX para o início do século XX, período marcado pelo crescimento urbano, principalmente no sudeste, o conceito de infância se desdobrou em outros significados. A criança deixa de ser objeto de interesse e preocupação do âmbito privado, tanto do famíliar quanto o da Igreja Católica, e torna-se uma questão pública e nacional. Portanto de competência do Estado.

A criança deixa de ocupar uma posição secundária e mesmo desimportante na família e na sociedade e passa ser percebida como valioso patrimônio de uma nação; como chave para o futuro, um ser em formação "ductil e moldável" - que tanto pode ser transformado em homem de bem (elemento útil para o progresso da nação) ou um degenerado (vicioso inútil a pesar nos cofres públicos). (RIZZINI, 2008, p. 24)

Setores elitizados do corpo social sudestino estavam atentos à infância desvalida, uma realidade que preocupava e gerou discussão, principalmente, entre médicos higienistas e intelectuais durante um período marcado pelo início do "Projeto Civilizador Republicano". Como resultado, a fidalguia pensante criou um aparato médico-jurídico-assistencial, cuja função era: a) Prevenir: vigiar para evitar a degradação; b) Educar: moldar para o trabalho e "bem viver"; c) Recuperar: reabilitar o "vicioso", um defeito grave de oposição às regras sociais; d) Reprimir: conter a delinquência.

O ato de tirar da família pobre a autoridade e o direito sobre os filhos, com base nesses quatro tópicos, era visto e defendido pela alta sociedade como uma medida profilática e de regulação social. Trata-se de um projeto político, predominantemente jurídico-assistencial, assentado na premissa de que o filho do pobre é um problema

\footnotetext{
${ }^{1}$ Entrevista de Mano Brown concedida a equipe da TV GAP (Bahia), programa Na Ativa. Junho de 2013. Fonte: https://www.youtube.com/watch?v=sxR0cimQID0. Acesso em: 07 nov. 2016. O Grupo Alerta Pernambués (GAP) foi criado no ano de 2001 por moradores do Bairro Pernanbués, na cidade de Salvador - BA, interessados em contribuir com questões sociais dos bairros periféricos. A TV GAP é o meio de comunicação, pelo qual, o grupo divulga ações, entrevistas, eventos que não tenham espaço na mídia graúda.
} 
social, seja em ação ou em potencial. Esse pensamento moderno matou a inocência infantil ao despir a libré de "anjinho", ou ser de "alma cândida", da criança pobre, vestindo-a de perigo para a sociedade.

Tal perspectiva dicotomizou a infância classificando-a em "criança" (mantida sob o cuidado da família que pode prover a prole) ou "menor" (que deve ser mantido sob a tutela vigilante do Estado) (RIZINI, 2008, p. 26-29). “Menor”, então, se tornou uma marca de distinção, uma etiqueta que, dependendo da situação, ganha, até, status de pronome de tratamento. Dos desdobramentos do termo, surgem categorias sociais como "menor abandonado" e "menor delinquente". Rótulos que, ainda hoje, estão presentes no vocabulário do senso comum quando o assunto é criança, adolescente ou jovem, principalmente a afro-brasileira/mestiça e periférica.

A presença do Estado no planejamento e implementação das políticas de atendimento aos menores abandonados e delinquentes deriva de um plano nacional. As leis de proteção e assistência à infância ocorrem com a criação, no Rio de Janeiro, do primeiro Juízo de Menores do país e do Código do Menor, na década de 1920. Promulgado pelo juiz de menores da América Latina, Dr. José Cândido de Albuquerque Mello, em 12 de outubro de 1927, o código estabelecia que:

\section{(...) Consideram-se abandonados os menores de 18 anos.}

I- Que não tenham habitação certa nem meios de subsistência, por serem seus pais falecidos ou desconhecidos ou por não terem tutor ou pessoa cuja guarda viva.

II- Que vivem em companhia de pai, mãe, tutor ou pessoas que se entreguem habitualmente à prática de atos contrários à moral e aos bons costumes.

III- Que se encontre em estado habitual de vadiagem, mendicância ou libertinagem.

IV- Que frequentem lugares de jogo ou de moralidade duvidosa ou andem na companhia de gente viciosa ou de má vida.

V- Que devido à crueldade, abuso de autoridade, negligência ou exploração dos pais, tutor ou encarregado de sua guarda sejam:

a- Vítimas de maus tratos-físicos e habituais ou castigos imoderados.

b- Privados habitualmente dos alimentos ou dos cuidados indispensáveis à saúde.

c- $\quad$ Excitados habitualmente para gatunice, mendigagem ou libertinagem².

\footnotetext{
2 https://www.planalto.gov.br/ccivil_03/decreto/1910-1929/D17943Aimpressao.htm. Acesso em: 01 out. 2015.
} 
"Delinquente" ou "abandonado", o menor era objeto de custódia do poder público e o código era o instrumento, ou melhor, o dispositivo jurídico que garantia a ação do Estado sobre ele. No caso, com o argumento de proteção e vigilância da infância e adolescência, as autoridades entendiam que tais jovens seriam vítimas de agressões e, também, omissão de famílias incapazes de garantir seus direitos básicos.

Com a implantação do Regime militar em 31 de março de 1964, mais uma série de mudanças com relação à problemática da criança e do adolescente foi estabelecida. Desse período temos o surgimento da FUNABEM (Fundação Nacional de Bem Estar do Menor), serviço que substituiu o SAM (Serviço de Atendimento ao Menor), criado durante a Era Vargas. A FUNABEM tinha olhos voltados para a segurança nacional, por isso, novamente, o pretexto foi a defesa da ameaça comunista. De 1967 até 1972, já em vigor a Política Nacional do Bem-Estar do Menor (PNBEM), a Fundação, com sua ação efetiva, institucionalizou aproximadamente 53 mil crianças e adolescentes. Estima-se que, durante seu funcionamento até o término da Ditadura Militar, a instituição atendeu entre 500 a 700 mil “menores". Desse total, pesquisadores contabilizaram 8\% de internações (RIZZINI; RIZZINI, 2004, p. 37).

Em São Paulo, com o decreto de 29 de dezembro de 1967, que criou a Secretaria da Promoção Social do Estado de São Paulo, o Serviço Social de Menores foi transferido para esta secretaria. Em pouco mais de um ano outro decreto fixou a estrutura da Secretaria da Promoção Social e criou a Coordenadoria dos Estabelecimentos Sociais do Estado (CESE), à qual ficou subordinado o atendimento ao jovem.

Além de administrar unidades destinadas à crianças e adolescentes, a CESE prestava atendimento a famílias carentes, migrantes, mendigos e alcoólatras, o que sobrecarregou o serviço. Diante do ônus problemático criou-se a Fundação Paulista de Promoção Social do Menor (Pró-Menor), em 1974. A ela foram agrupadas todas as unidades de atendimento aos jovens e crianças. Em 1976, a Secretaria de Promoção Social mudou o nome da Fundação Pró-Menor para Fundação Estadual do Bem-Estar do Menor (Febem/SP), uma adaptação à política federal em vigor.

No ano de 1979 surge o novo código de menores, em substituição àquele de 1927. Nesse código aparece a categoria "menor em situação irregular", fato que não 
difere do regulamento anterior, pois continuou expondo, à intervenção do Estado, famílias localizadas às bordas da sociedade, por conta de sua condição de pobreza.

Promulgado no Ano Internacional da Criança - lei 6.697, de 10 de outubro de 1979 - o Código apregoava que o Juiz de Menores tinha autorização total para aplicar as medidas cabíveis, caso o menor de 18 anos estivesse enquadrado nestas condições de irregularidades:

Art. $2^{\circ}$ - Para efeitos deste código, considera-se em situação irregular o menor: I - Privado de condições essenciais à sua subsistência, saúde e instrução obrigatória, ainda que eventualmente em razão de:

a) falta, ação ou omissão dos pais ou responsável;

b) manifesta impossibilidade dos pais ou responsáveis provê-las;

II- Vítima de maus-tratos ou castigos imoderados impostos pelos pais ou responsável;

III- Em perigo moral, devido a:

a) encontrar-se, de modo habitual, em ambiente contrário aos bons costumes;

b) exploração em atividade contrária aos bons costumes;

IV- Privado de representação ou assistência legal, pela falta eventual dos pais ou responsável;

V- Com desvio de conduta, em virtude de grave inadaptação familiar ou comunitária;

VI- Autor de infração penal. ${ }^{3}$

Na década de 1980 e início de 1990, período marcado pelas ações de vários movimentos sociais, que resultou na criação e implantação do Estatuto da Criança e do Adolescente (ECA), amplia-se o debate sobre a tutela da infância e da adolescência para outros setores do corpo social. Os pontos de partida foram: a) a tutoria e a real funcionabilidade das instituições de acolhimento às crianças e aos adolescentes; b) a criança em situação de rua; c) a ineficácia do sistema de cárcere infanto-juvenil; d) a família.

O Estatuto criou instâncias de fiscalização nas comunidades, que passaram a utilizar mecanismos de defesa e proteção de interesses coletivos, até mesmo em casos de transgressão por parte das autoridades públicas. Isto implicou maior participação de civis, tanto na discussão referente às questões da infância e da adolescência quanto no processo de mediação e intervenção familiar, entre outras especificidades.

\footnotetext{
${ }^{3}$ https://www.planalto.gov.br/ccivil_03/LEIS/1970-1979/L6697impressao.htm. Acesso em: 01 out. 2015. 
A infância abandonada nos centros das grandes metrópoles e o recrudescimento da violência nas inúmeras rebeliões na extinta Febem, em São Paulo, chocavam a sociedade e indicavam a fragilidade e a falência do modelo em relação ao tratamento dado aos jovens. O litígio em torno da questão do "menor" e suas múltiplas categorias - abandonado, delinquente, desvalido, desamparado, vicioso, transviado, desassistido, carente, de conduta antissocial, vadio, vagabundo, mendigo, libertino, desajustado ou em situação irregular - deixam de ser exclusividade dos intelectuais, juristas e assitencialistas.

A sociedade civil enverga para si a conversa e, diante de um sentimento nacional de indignação, arma-se uma enorme mesa-redonda envolvendo educadores, psicólogos, assistentes sociais, pedagogos, historiadores, sociólogos, filósofos, clérigos, médicos, jornalistas, advogados e artistas de diversos nichos.

A luta para a democratização do país desde a década de 1980 vem trazendo, ainda que em gotas, a população para dentro de discussões centrais, abordando diversas temáticas de múltiplos interesses. Para os interesses do artigo os trabalhos das pesquisadoras Irene Rizzini e Irma Rizzini (2004) apontam para a ineficácia e a violência dos últimos cem anos das políticas voltadas à infância e a juventude. Atualmente, o debate no seio social sobre a temática apresentada está novamente em evidência e, ainda, não se desgarrou do peso secular do termo classificatório criado por juristas e intelectuais. A criança e os adolescentes pobres, marjoritariamente de ascendência afro-brasileira/mestiça e ameríndia continuam sendo tratados como "menores", mesmo quando não são assim chamados.

Pouco antes e durante os primeiros passos do ECA, que permitiu uma maior participação de pessoas sem vínculos profissionais específicos na disputa tutorial sobre a juvenilidade em situação de risco social, artistas de rap das periferias de São Paulo abordaram a temática em seus projetos artísticos. Adiante, analiso quatro peças musicais, sendo uma delas confeccionada por múltiplas mãos, denominada "Menor Abandonado". 


\section{O tema}

O fazer musical da juventude periférica de São Paulo, na passagem da década de 1980 e início dos anos 1990, está ligado às vivências dos artistas na elaboração e realização de suas artes. Tais experiências formam um produto cultural que evidenciou uma visão de mundo marcada pela desigualdade, racismo, violência física e psíquica, rebaixamento e tentativas de silenciamento. Ao mesmo tempo, anunciou-se um ideal de desenvolvimento endógeno. Neste sentido, são produções que sintetizam as experiências históricas e as percepções da realidade ao redor, criando um corpo único de reflexões sobre sonoridade, modernidade, brasilidade e sociedade.

Nota-se que as composições dos raps, a partir de 1988/1989, passam a ser assinadas por artistas do gênero e não mais por produtores comerciais, vinculados à indústria fonográfica hegemônica. À medida que os artistas vão se apropriando da concepção e da elaboração da canção, a musicalidade se transforma e gradativamente, passa a apresentar feições de criação autoral. Essas gravações, ao serem historicizadas, trazem à tona o engajamento dos artistas em uma atividade política de amplo aspecto (BOTELHO; GARCIA; ROSA, 2016, p.171-201), cujo objetivo principal, implícito, é a promoção do desenvolvimento da periferia. Maria Rita Kehl (2000, p. 209-244) entende essa praxe como um esforço civilizatório, característico do rap produzido nos bolsões de pobreza urbana. Sendo assim, ela explica esse esforço como:

(...) a capacidade de simbolizar a experiência "destes" milhões de periféricos urbanos, de forçar a barra para que a cara deles seja definitivamente incluída no retrato atual do país (...) é a capacidade de produzir uma fala significativa e nova sobre a exclusão. (KEHL, 2000, p. 215).

A pesquisadora Wivian Weller (2011, p. 33), em seu estudo sobre manifestações juvenis em Berlim e São Paulo, nos apresenta um breve histórico do rap paulistano. Conforme sua periodização, no início da década de 1990 os temas abordados pelas canções estão, em sua maioria, associados às pautas políticas do Movimento Negro Unificado (MNU).

A partir de 1993, na terceira fase, há uma centralização temática, cujo foco principal é a periferia urbana (no caso de São Paulo, a presença afro-brasileira/mestiça 
é majoritária nesses espaços) e suas problemáticas. Nesse momento, segundo Weller (2011, p. 34-5), o "Movimento" Hip-Hop paulistano adquire maior autonomia, resultante de um processo de amadurecimento. Essa emancipação do discurso aparece nas composições e nas estéticas das músicas. Escutando atenciosamente as gravações, pode-se observá-la em diversos pontos: nas escolhas dos sons sampleados ${ }^{4}$, na performance, na dicção, na impostação da voz, assim como na disposição dos efeitos na estrutura musical; quero dizer, o lugar do scratch ${ }^{5}$. A comunicação que a música transmite faz com que a projeção transcenda para além de uma perspectiva mercadológica e o artista de rap vai se apresentar como cronista e mediador de questões culturais, sociais e políticas.

Athalyba-Man, um dos primeiros artistas de rap a assinar com uma das gravadoras majors, que apostaram na força comercial do gênero, começou sua carreira no final dos anos 1980. Sua obra pode ser compreendida em dois momentos: a) o início junto ao coletivo Região Abissal, com o qual lançou dois discos; b) sua projeção como artista solo, com trabalhos em 1993 e 1994. No ano do centenário da abolição da escravidão, 1988, saiu pelo selo Continental o disco HipRapHop (REGIÃO ABISSAL, 1988, LP), seu primeiro projeto artístico. Das dez músicas do LP, seis levam sua assinatura, inclusive a carro chefe "Sistemão" (REGIÃO ABISSAL, 1988, faixa 2, lado A). Nessa peça musical, o artista interpreta um menino em situação de rua, espacializado na Praça da Sé, falando em primeira pessoa diretamente para o ouvinte. Em seu trabalho solo, na década de 1990, Athalyba-Man volta a abordar a questão da criança em situação de risco na música "Profissão Ladrão - Sistemão II" (ATHALYBA-MAN, 1994, faixa 11). Porém, nesse segundo momento, o menino já se tornou ladrão. Entende-se que o foco maior, anunciado pelo artista, está na consequência, sendo este um fato que afeta toda a sociedade.

\footnotetext{
${ }^{4}$ Sampler é um aparelho que registra, analisa, transforma e reproduz ondas sonoras de todo tipo. A técnica de sampleamento consiste em extrair de uma gravação algum trecho da construção musical e utilizá-lo para construir uma nova música. Ver: D'alva (2014, p. 15) e Wisnik (1989, p. 48).

${ }^{5}$ Scratch consiste em uma técnica de movimentar o long play, onde o Disc Jóquei (aquele que manipula os toca-discos) desconfigura o som da gravação, transformando-o em um efeito sonoro. Auscultando as obras do período em estudo, nota-se que o DJ ganha destaque e assume um papel mais atuante na construção da canção. Entendo que o lugar do scratch na música representa parte importante da estrutura, compondo conjuntamente com a letra o gesto de revide. Tal gesto, presente no texto e característico do rap, foi levantado pelo pesquisador e músico Walter Garcia (2013) em seus estudos sobre os Racionais $\mathrm{MC}^{\prime} \mathrm{s}$
} 
Nas duas peças musicais há a presença do tema, mas não há menção ao termo "menor". Na primeira canção, utilizando-se do recurso da representação, ele incorpora um garoto que se apresenta agressivo, mas também dócil conforme a conveniência. Da parte amigável para o lado grosso da personagem, há um crescente na tonalidade da voz do MC. No primeiro momento, a complementação entre os dois corpos vocais é bem marcada. Vejamos um exemplo utilizado pelo artista a fim de criar uma estrofe solo e outra de reforço, como recurso enfático do texto;

\author{
Se for na valentia, na minha não se cria/ (Athalyba-Man) \\ Se não pegar na mão/ (Athalyba-Man e Coro) \\ Eu to falando grosso e isso é só o esboço/(Athalyba-Man) \\ Do meu lado mau/ (Athalyba-Man e Coro) \\ Mas se for meu amigo, a gente aperta um/(Athalyba-Man) \\ Até faço esta presa/ (Athalyba-Man e Coro) \\ Religião não sei, de sexo conheço/(Athalyba-Man) \\ Ouvir falar da AIDS/ (Athalyba-Man e Coro) \\ Mas nunca li um jornal, nunca peguei teatro/(Athalyba-Man) \\ Eu nunca fui na escola/ (Athalyba-Man e Coro) \\ Eu sei joga uma bola, o meu barato é furto/(Athalyba-Man) \\ Eu cheiro é muita cola/ (Athalyba-Man e Coro) \\ (REGIÃO ABISSAL, "Sistemão", 1988)
}

Antes do término do segundo momento, o principal corpo vocal se destaca, não dando espaço para o reforço em coro. Gradativamente, a dicção da personagem vai se tornando mais agressiva. Na música é possível perceber, mas aqui na transcrição adiante, destaco em negrito;

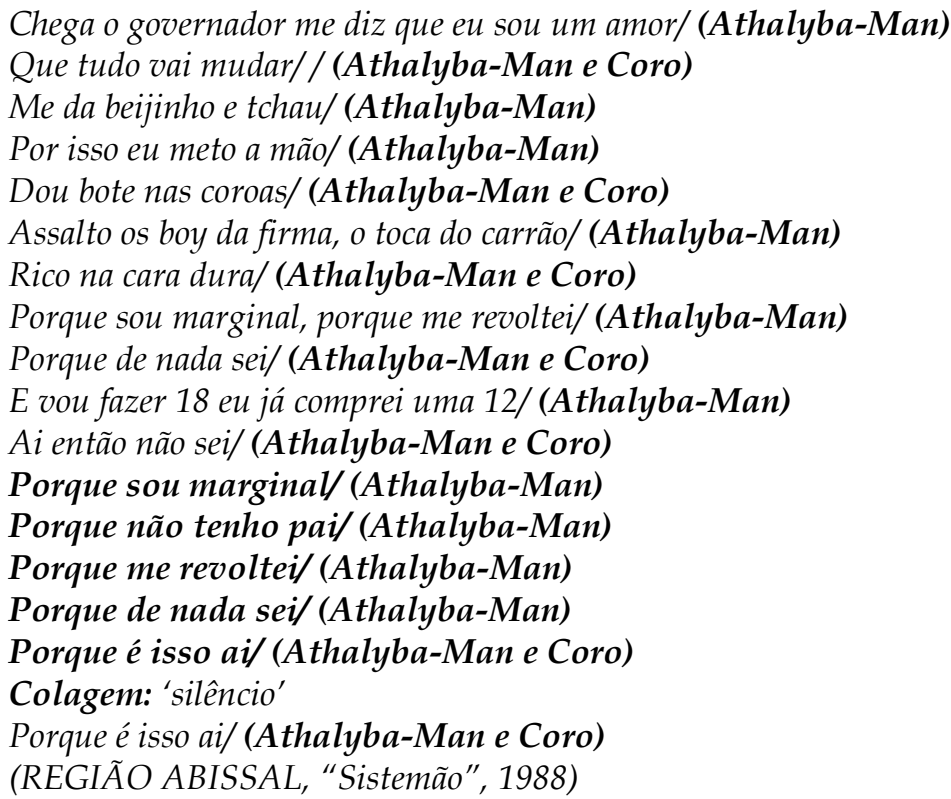


Conforme pode-se observar, a guinada tem início com a percepção da má intenção do político profissional. Um sentimento de indignação anuncia o estopim e numa escalada progressiva se chega ao ápice da cólera, representada na impostação de voz do MC, cujo esforço performático dispensa o segundo corpo vocal. O tom alarmante, o que é emergencial, fica evidente tanto no canto, quanto na construção sonora. Os dois DJs completam a composição com uma colagem pedindo silêncio e uma reprodução de sirene. Não há diálogo com o ouvinte. Pede-se silêncio e ao mesmo tempo atenção, pois quem está falando é alguém que, até então, não tinha voz. Essa performance de Athalyba pode ser compreendida como uma pré-experiência daquilo que Roberta Estrela D'alva denominou ser Ator-MC6.

Na segunda peça musical, "Profissão Ladrão - Sistemão II", há um revezamento do narrador entre a primeira e a terceira pessoa. O MC ora observa de fora, ora é protagonista. A personagem perdeu a ternura ("compaixão o caralho/"), não é mais criança, cresceu filha da rua e não há mais o que fazer. Seu futuro era previsível e nada se fez para evitar o processo de entrada no crime, na qual ganhou "dignidade".

Por que ladrão, é a profissão que me dignifical

No seio da malandragem levo vida rical

Com pó, de mulher nunca fico só/

(ATHALYBA-MAN, "Profissão Ladrão - Sistemão II", 1994)

Entre a soma e o resto, o resultado nos é apresentado com as duas mortes da figura principal, a social e a física, causadas pela invisibilidade vigiada e extermínio.

E ficam discutindo sobre o que fazer/

Com mais um menino que agora cresceu/

E ficam liquidando, ficam exterminando/

Antes um menino, mas agora cresceu/ (Ladrão!)

(ATHALYBA-MAN, "Profissão Ladrão - Sistemão II", 1994)

Athalyba-Man deixa explícito a sua indignação, que, por sua vez, é fortemente marcada por um ceticismo. Um sentimento que não é irremediável, mas

\footnotetext{
${ }^{6} \mathrm{O}$ conceito de Ator-MC foi desenvolvido pela artista e pesquisadora Roberta Estrela D'alva, por meio de seu trabalho com o grupo de teatro Núcleo Bartolomeu Dias. Em suas palavras: "O ator-MC é um artista híbrido que traz na sua gênese as características narrativas do ator épico (o distanciamento, o anti-ilusionismo, o gestus, a determinação do pensar pelo ser social), mixado ao autodidatismo, à contundência e ao estilo inclusor, libertário e veemente do MC" (D'ALVA, 2014, p. 75-76).
} 
cumpre papel de cunho apelativo para o ouvinte. Nas peças musicais analisadas, a humanização da personagem é posta lado a lado com sua aspereza e contraposta com o seu destino. Nota-se que a violência é entendida como ponto nevrálgico e efeito colateral de um imbróglio. A criança perde sua candura por meio de um processo de marginalização. Nesse quesito, o artista é enfático em seu ponto de vista. Quanto maior a falta de ação da sociedade frente ao fato, maior o gesto hostil do garoto em situação de risco, chegando à violência descontrolada e inconsequente.

O grupo Balinhas do Rap, grupo formado por dois DJs (Killer e Dobow T), dois dançarinos (Marcel e Eduardo) e dois MCs (Cássio e André), começou sua carreira no final dos anos 1980 e o primeiro registro fonográfico data de 1991, com participação em uma coletânea chamada Movimento Rap. O projeto artístico Menor Abandonado (OS BALINHAS DO RAP, 1992, LP) com produção fonográfica pela gravadora independente Rythym and Blues e produção artística feita por DJ Grand Master Ney, DJ Cuca, DJ Dobow T e Duck Jam, foi lançado em 1992. A obra tem como tema central a adolescência e as canções se dividem, no LP, da seguinte forma:

\begin{tabular}{|l|l|}
\hline Lado A & Lado B \\
\hline Moleques de Rua & Menor abandonado \\
\hline Corrupção Policial & Matas verdes \\
\hline Droga e violência não & Rap do cacuete \\
\hline Não escolha este caminho & Bagunça dos Balinhas \\
\hline
\end{tabular}

A música em negrito foi assinada por 15 artistas e um radialista, Natanael Valêncio ${ }^{7}$. Conta com diversos samplers, como os da banda The Honey Drippers com a música "Impeach The President", entre outros. Mas o principal é de James Brown, “Papa Don't Take No Mess My Thang”. A canção é uma bricolagem e chega ao ouvinte com um formato não convencional, percebe-se ausência de um eixo estrutural fixo e não há estabilização melódica. Trata-se de uma composição que conta com quatorze

\footnotetext{
${ }^{7}$ Natanael Valêncio (in memorian) realizou, em parceria com o DJ Grand Master Ney, o programa Movimento Rap transmitido pela rádio imprensa de 1988 a 1999. Vale dizer, também, que Natanael foi um dos fundadores da Gravadora independente Rythym and Blues. A essa informação, devo créditos ao artista Luiz Preto, do conjunto musical Caos do Subúrbio, em nossas conversas sobre Hip Hop.
} 
versos e quatro refrães, onde cada trecho foi composto por um artista diferente. Há um diálogo, um verso e o refrão; na sequência, cinco versos e novamente o refrão, depois mais sete versos e a volta para o refrão. O último verso é marcado pela presença de dois artistas encenando uma rápida prosa e os dois últimos refrães são cantados em coro por todos os participantes. A distância entre os refrães não segue uma lógica de canção comercial, marcada milimetricamente.

Característico do rap old school, a abertura é uma performance em dueto, em que André e Cássio apresentam a temática:

- E ai André, tudo bem?

- Eu estou, quem não está é o menor abandonado! E por ele não fazemos nada, isto me deixa indignado!

(BALINHAS DO RAP, "Menor Abandonado", 1992)

Na sequência tem-se a transição da fala para o canto-falado. Ouve-se, então, o primeiro verso com uma impostação de voz que reforça o texto:

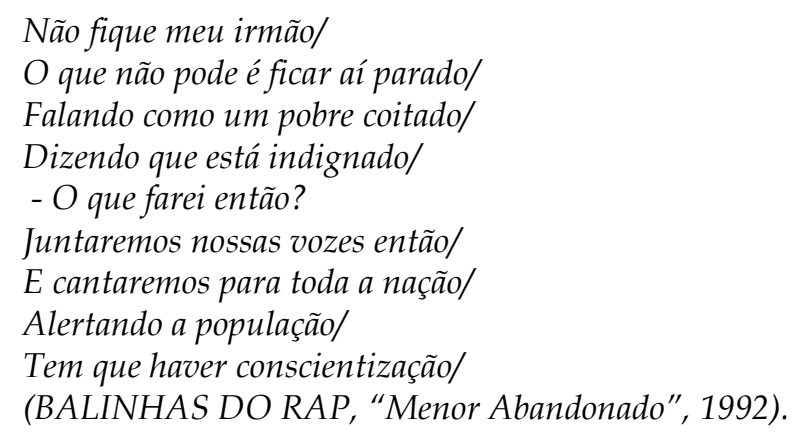

Neste começo, o que chama a atenção são algumas palavras apresentadas: "indignado", "alertando", "nação" e "conscientização". Elas formam a base do discurso e evidenciam a espinha dorsal do diálogo com a sociedade. "Indignação" é um sentimento de cólera provocado por diversas razões; para o que aqui nos cabe, a injustiça social, que permeia o tema, é revoltante para parcela considerável da sociedade. "Alerta" pode ser compreendido como um sinalizador daquilo que é emergente. Por "nação", entendemos ser o corpo social. E "conscientização" é a chamada para o ouvinte refletir e agir sobre uma questão pertinente à sociedade brasileira como um todo.

Os Balinhas do Rap juntaram as vozes de diversos cantores de rap e promoveram, em forma de canção, um colóquio que corre por quatro minutos e meio. 
Os partícipes explanam opiniões, apontam culpados para a conjuntura que desperta indignação e convidam o ouvinte a participar da querela.

O rótulo "menor" não é debatido diretamente. Entretanto, na leitura minuciosa da letra e na escuta, percebe-se que a palavra aparece em todos os refrães e mais sete vezes no decorrer da música. Está no início e nos versos de Mister Theo, Eazy Jay, MC Jack, Natanael Valêncio, Face Negra e Master Rap. Apresento recorte do décimo verso, com performance do grupo Face Negra:

\author{
Nós devemos ajudar nossas crianças/ \\ No centro de São Paulo são chamado de pivete e delinquente/ \\ Influentes do crime como dizem/ \\ Olha o menor abandonado irmão/ \\ (BALINHAS DO RAP, “Menor Abandonado”, 1992).
}

A primeira estrofe chama para a conscientização; na segunda e na terceira, mostra-se a indignação com as classificações dadas aos jovens; na última, o canto falado ganha força com a execução momentânea de uma batida seca, ou seja, ausente de acompanhamento harmônico. Esse capricho da construção musical dá ênfase à performance do $\mathrm{MC}$, reforçando o pedido de atenção ao ouvinte.

O mais interessante é que os artistas do Face Negra (assim como outros que atuam na mesma música) reconhecem que a protagonista do debate é apenas uma criança e, ainda destacam, que é chamada de "pivete", "delinquente" e "influente do crime". A força classificatória com carga pejorativa vem de um olhar externo ao dos rappers e é contraposta à candura da palavra "criança", que está antecedida por um pronome possessivo, destacando o locus de enunciação do artista ao lado das crianças.

A representação em diálogo que enceta a peça musical aponta que o "menor" não está bem. Ao final da canção, com presença de dois corpos vocais em canto antifonal, André interpreta um garoto e Thaíde um adulto:

\footnotetext{
Todo dia três de vocês vão dormir com os anjos/(Thaíde) Como mostra o seu álbum de infância/ (Thaíde) Olhos raso d'água lábios tremendo/(Thaíde) Você tem alguma coisa a me dizer criança?/ (Thaíde) Banho, só se for de chafariz/ (André) Um brinquedo automático que eu sempre quis/ (André) É por isso que dou bote em relógio de otário/ (André) Peço bicho bem barato e assim sou feliz/ (André) Sua vida é triste e você acha que é feliz/ (Thaíde)
} 
Essa Felicidade tem que acabar de vez/ (Thaíde)

Pode crê Thaíde \& DJ Hum com vocês/ (Thaíde)

(BALINHAS DO RAP, "Menor Abandonado", 1992).

Nessa representação, o menino em situação de rua, conhecido como "menor abandonado", é tratado acentuadamente pelo substantivo "criança".

$\mathrm{O}$ ato de interpetrar uma personagem é um artifício que aparece em várias canções de rap. O diálogo é o recurso que reforça a mensagem e o tema, chamando a antenção do receptor por meio da representação. O ouvinte, em contato com a canção em análise, é impelido a se posicionar, opinar e agir, pois Os Balinhas do Rap, como mediadores de questões sociais, "mandam a mensagem pra você". Mandar, nesse contexto, perde sua força imperativa e ganha outra acepção, passando a ser compreendido como transferir. Todos os participantes mandam uma mensagem (sobre a criança em situação de risco social) nessa peça musical simulacro de fórum temático. O refrão é o alerta, um alarme que anúncia uma emergência, sendo reiterado efusivamente:

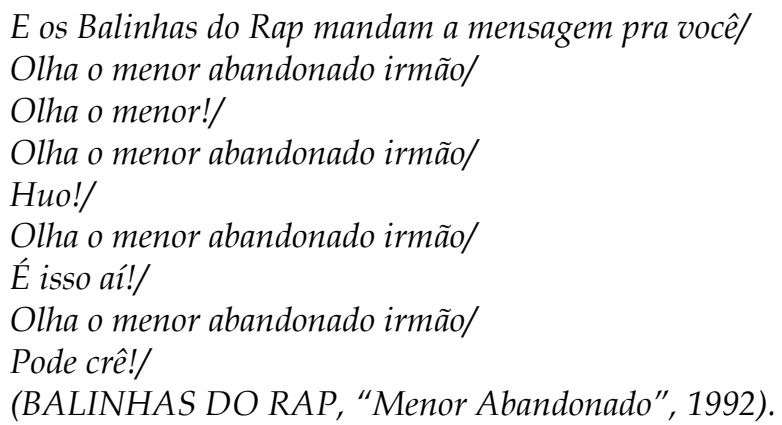

No ano de 1994 chega às lojas um LP de rap intitulado Quebra Tudo!, do grupo Produto da Rua. A principal canção dessa obra é uma composição de Marcos Telesphoro e Kult denominada "Durma com os anjos" (PRODUTO DA RUA, 1994, faixa 1). O diálogo no início dessa peça musical mostra o sentimento de indignação dos intérpretes Phanter e Kult;

São Paulo garoa fina...

Nós andávamos pelo centro parecia ser o dia mais frio

de todos os tempos, eu e o Phanter reclamávamos de nossas roupas, blusas e tocas, nada esquentava.

Foi então que uma visão de um garoto nos deixou chocado:

- Olha lá Kult, eu juro que não acredito no que vejo:

é um garoto só de shorts, sem camisa e cheirando cola!

E nesse tempo?

Infelizmente Phanter nem todos pais são os pais mesmos, 
na falta de carinho;

afeto, educação, compreensão e respeito, fazem uma

criança viver desse jeito.

(PRODUTO DA RUA, “Durma com os anjos", 1994).

Após a introdução, o primeiro verso é interrompido por um terceiro corpo vocal. Trata-se de um pedido em forma de pergunta. Começa um diálogo que orienta a atenção do audiente para esta personagem, um garoto;

- Hei tio, o senhor não tem nenhum trocado pra me dar aí não?

- Depende, você tá indo pra onde?

Estou andando sem destino e não tenho onde morar/

já são dois dias que eu não como/

o chão gelado é a minha camal

e minha cola é para me esquentar/

- Mas e aí tio, o senhor vai dá ou não vai dá?

- Vamo colar naquele bar que eu te pago um lanche, pão com

manteiga; um chocolate! Mas e aí irmãzinho, qual é a sua idade?

Tenho 11 de idade mas não vem me engrupir/

Frequento sempre o S.O.S. e a FEBEM era uma casa pra mim/

Na vida já aprendi muitas coisas/

poucas boas, muitas ruins/

- E os seus pais? Família?

- Eles não gostam de mim, melhor assim. Aliás, nem sei por que eu nasci. Aí tio, depois desse lanche eu vou dormir!

(PRODUTO DA RUA, “Durma com os anjos", 1994).

O mise-en-scène antes do primeiro refrão apresenta os atuantes: os dois cantores e um garoto em situação de rua; sendo este a principal personagem, pois representa o foco temático. Sua narrativa de vida é carregada de gírias expostas com tonalidade agressiva. Eis o esboço de seu lado mau, que é quebrado com o gesto do MC Kult ao perguntar sobre a família. A resposta vem com outra dicção, mais dócil, uma fala pueril que passeia pela inocência. O termo "menor" aparece no segundo momento da música, depois de desfeita a imagem de impetuoso do menino, e está colado à ideia de um propósito político. Ou seja, entende-se que o termo tem uso específico, referente a assuntos instituicionais e não tem força representativa no léxico do cantor, em que se enfocam as palavras "pequenos irmãos" e "criança";

Fazer campanha na televisão/

Diz que o menor é prioridade/

Fizeram o Estatuto da Criança na Constituição/

Quem?/

Aqueles que descriminam nossos pequenos irmãos/

E o tratam como lixo/ 


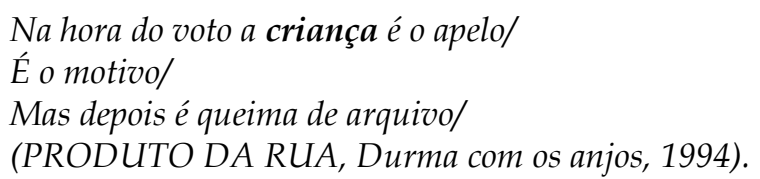

Nota-se que o garoto, desde o início, está exposto a tudo, quase nu, "só de shorts, sem camisa" e, no decorrer da canção, tem duas mortes. Uma é a social, causada pela invisibilidade imposta, representada na estrofe "Mas depois é queima de arquivo". E a outra é a física, marcada pela visibilidade (o ato bárbaro ocorre na praça da Sé, centro da cidade) representada pelas estrofes "Morto ali estava o meu pobre menino/ com seu corpo aberto (...)". A crueldade com que ele é assassinado é o apelo maior para o ouvinte, um sensacionalismo comovente; afinal de contas é a morte de um pobre menino. Este agora irá dormir com seus pares, os anjos.

\section{O rap é compromisso!}

A produção de rap old school, ou da velha escola, na década de 1980 e início dos anos 1990, foi caracterizada por ampla atividade política, passando pela difusão da perspectiva de desenvolvimento endógeno da periferia, denúncias de racismo contra afro-brasileiros, machismos, violência policial, violência institucional, violência emocional, entre outras. No que aqui apresento, a contraposição "criança" x "menor" é mais uma das ações de humanização presentes nas canções. Presença que aponta para o posicionamento dos artistas no debate sobre a disputa tutelar da infância.

No campo da performance nota-se, nas músicas analisadas ${ }^{8}$, um frequente uso da representação com diálogos. Essas performances compreendem um conjunto de atos de transferência (TAYLOR, 2013, p. 25-90), ou seja, transmitem saberes sociais, memórias, denúncias e percepções através de atos artísticos. Sua força está em levar para o ouvinte o texto musicado com grau de seriedade incontestável, uma verdade

\footnotetext{
${ }^{8}$ Ressalto que não é intuito, nesse artigo, analisar todas as obras que tratam do tema "criança em situação de risco". Para o pesquisador interessado, recomenda-se a audição de outras peças musicais, tais como: Racionais MC's, em “Mágico de Oz" (1997); e a dupla brasiliense Baseado nas Ruas, em “Retalhos da Sociedade" (1992). A coletânea chamada Tiro Inicial, que lançou MV Bill e Gabriel o Pensador, foi um projeto carioca de 1993 com participação de vários artistas. A música "Filhos do Brasil" merece atenção.
} 
absoluta. Erving Goffman, em sua obra A Representação do Eu na Vida Cotidiana, mostranos suas observações sobre o ato de representar. Em suas palavras:

\begin{abstract}
Quando um indivíduo desempenha um papel, implicitamente solicita de seus observadores que levem a sério a impressão sustentada perante eles. Pede-lhes para acreditarem que o personagem que veem no momento possui os atributos que aparenta possuir, que o papel que representa terá as consequências implicitamente pretendidas por ele e que, de modo geral, as coisas são o que parecem ser. Concordando com isso, há um ponto de vista popular de que o indivíduo faz sua representação e dá seu espetáculo "em benefício de outros". (GOFFMAN, 1975, p. 25.)
\end{abstract}

Não cabe aqui discutir a convicção do indivíduo receptor diante da peça musical. Interessa notar que a representação, com expectativa plena de crença por parte de quem anuncia, era um recurso bem aproveitado nos raps para que os objetivos fossem alcançados. Pelo tema em questão, tal propósito fica evidente no vigor performático, visto que os artistas procuram tirar o rótulo de "menor" da criança, devolvendo assim a candura da infância para os nossos infantes em situação de risco social.

O selo "menor", que foi colado no tecido da criança afro-brasileira/mestiça e pobre, continua sendo a injusta distinção que garante a violenta ação de institucionalização, quando não o extermínio, por parte do Estado. A intervenção legal em famílias pobres, garantida antes pelo extinto Código do Menor, foi uma das ações mais criticadas por profissionais de diversas áreas que atuam com a questão. Porém essa prática ainda está em voga e com alta aceitação por parcela considerável da sociedade, mobilizada e mobilizadora da opinião pública.

Estudos utilizados para a produção deste artigo consideram essa prática um ponto nevrálgico, com raízes históricas e que diz respeito à facilidade com que se institucionalizam crianças e adolescentes no Brasil, principalmente afrobrasileiras/mestiças e afro-brasileiros/mestiços e a cultura que se criou em torno disso. Cultura que atinge o imaginário de parte da população, desde o juiz ao simples cidadão de bem. Cidadão, esclarecido, que anda temeroso da violência e do ódio dos "menores infratores, delinquentes juvenis". 


\section{Referências}

ABREU, Martha; SOIHET, Rachel; GONTIJO, Rebeca (orgs). Cultura politica e leituras do passado: historiografia e ensino de história. Rio de Janeiro: Civilização Brasileira, 2007.

BOTELHO, Guilherme; GARCIA, Walter; ROSA, Alexandre. Três raps de São Paulo: "Política", Athalyba-Man (1994); "O menino do morro", Facção Central (2003); "Mil faces de um homem leal (Marighella)", Racionais MC's (2012). In: LACERDA, Marcos (Org). Música. Ensaios Brasileiros Contemporâneos. Rio de Janeiro: Funarte, 2016.

D'ALVA, Roberta Estrela. A Cultura Hip-Hop como matriz. In: a performance poética do ator-MC. São Paulo: Perspectiva, 2014. . Teatro Hip-Hop:

GARCIA, Walter. Elementos para a crítica da estética do Racionais MC's (1990-2006). Ideias, no7. Campinas: IFCH-Unicamp, 2013. v. 1.

GOFFMAN, Erving. A representação do Eu na vida cotidiana. Petrópoles: Editora Vozes, 2011.

KEHL, Maria Rita. A fratria orfã: o esforço civilizatório do rap na periferia de São Paulo. In: (org.). Função Fraterna. Rio de Janeiro: Relume Dumará, 2000.

PASSETI, Edson. O que é menor? São Paulo: Editora Brasiliense, 1982.

RIZZINI, Irene; RIZZINI, Irma. A institucionalização de crianças no Brasil: percurso histórico e desafios do presente. Rio de Janeiro: Editora EDUC, 2004.

RIZZINI, Irene. O Século Perdido: raízes históricas das políticas públicas para a infância no Brasil. São Paulo: Cortez, 2008.

TAYLOR, Diana. Performance e memória cultural nas Américas. Belo Horizonte: Editora UFMG, 2013.

WELLER, Wivian. Minha voz é tudo o que tenho: manifestações juvenis em Berlim e São Paulo. Belo Horizonte: Editora UFMG, 2011.

WISNIK, José Miguel. O Som e o Sentido: uma outra história das músicas. São Paulo: Companhia das Letras, 1989. 


\section{Discografia}

ATHALYBA-MAN. Athalyba e A Firma. São Paulo: BMG, 1994.

BASEADO NAS RUAS. Baseado nas Ruas. TNT Records, 1992.

OS BALINHAS DO RAP. Os Balinhas do Rap e seus Amigos. Menor Abandonado. São Paulo: Rythym and Blues, 1992. LP.

PRODUTO DA RUA. Quebra tudo. São Paulo: M.A Records, 1994. LP.

RACIONAIS MC'S. Sobrevivendo no Inferno. São Paulo: Zambia, 1997.

REGIÃO ABISSAL. HipRapHop. Continental, 1988.

V.A. Tiro Inicial. Radical Records, 1993. 